\title{
BMJ
}

\section{The effect of high dose inhaled corticosteroids on wheeze in infants after respiratory syncytial virus infection: randomised double blind placebo controlled trial}

\author{
Marieke J J Ermers, junior research fellow, ${ }^{1}$ Maroeska M Rovers, epidemiologist , ${ }^{2}$ Job B van Woensel, \\ paediatrician, intensive care specialist, ${ }^{3}$ Jan L L Kimpen, professor of paediatric infectious diseases, \\ Louis J Bont, paediatrician, infectious diseases specialist ${ }^{1}$ on behalf of the RSV Corticosteroid Study Group
}

Department of Paediatric

Infectious Diseases, Wilhelmina

Children's Hospital, University

Medical Centre Utrecht,

PO Box 85090, 3508 AB Utrecht, Netherlands

2Julius Centre for Health Sciences and Primary Care, University

Medical Centre Utrecht,

Netherlands

${ }^{3}$ Department of Paediatric Intensive Care, Emma Children's Hospital, Academic Medical Centre, Amsterdam, Netherlands Correspondence to: L J Bont l.bont@umcutrecht.nl

Cite this as: BMJ 2009;338:b897 doi:10.1136/bmj.b897

\section{ABSTRACT}

Objective To determine whether early initiated antiinflammatory therapy with prolonged high dose inhaled glucocorticoids influences the occurrence and severity of recurrent wheeze after respiratory syncytial virus related lower respiratory tract infections.

Design Randomised double blind placebo controlled trial. Setting Paediatric departments of 19 Dutch clinical centres.

Participants 243 previously healthy infants (126 boys, 117 girls) aged less than 13 months and admitted to hospital with respiratory syncytial virus infection. Interventions $200 \mu \mathrm{g}$ extra fine hydrofluoroalkane (HFA) beclometasone dipropionate twice daily or matched placebo administered by a pressurised metered dose inhaler and a spacer during the first three months after hospital admission.

Main outcome measure The primary outcome was the number of days with wheeze in the year after the three month intervention period.

Results Of the 243 eligible infants, 119 were randomised to receive beclometasone and 124 to receive placebo. No significant difference was found in the number of days with wheeze between the two groups (total days, 1761/ 33568 in the beclometasone group $v 2301 / 36556$ in the placebo group, $\mathrm{P}=0.31$ ) and the proportion of infants with wheeze did not differ between the groups (61\% in the beclometasone group $v 62 \%$ in the placebo group, $\mathrm{P}=0.90$ ). In the predefined subgroup of infants who did not need mechanical ventilation $(n=221)$, beclometasone reduced the number of days with wheeze by $32 \%$ (relative reduction in total days, 1315/30405 in the beclometasone group $v 2120 / 33149$ in the placebo group, $\mathrm{P}=0.046)$. This reduction was most pronounced during the first six months of the follow-up year after intervention. The proportion of infants with wheeze did not differ between the groups ( $59 \%$ in the beclometasone group $v 60 \%$ in the placebo group, $\mathrm{P}=0.89$ ).

Conclusions Early initiated high dose extra fine HFA beclometasone to infants during the first three months after hospital admission for respiratory syncytial virus infection has no major effect on recurrent wheeze. The general use of such treatment during lower respiratory tract infection with respiratory syncytial virus should not be advocated.

Trial registration Current Controlled Trials ISRCTN12352714.

\section{INTRODUCTION}

Respiratory syncytial virus related lower respiratory tract infection is the most common cause of infants being admitted to hospital during winter and is often followed by recurrent transient episodes of wheeze. ${ }^{1-3}$ Recurrent wheeze after respiratory syncytial virus infection has a high prevalence, ${ }^{4}$ influences quality of life, ${ }^{5}$ and generates substantial healthcare costs. ${ }^{6}$

It has been hypothesised that the infection and concomitant inflammatory reaction in the acute phase of the infection leads to recurrent wheeze. ${ }^{7}$ In line with this hypothesis, immune modulation during the acute phase might influence recurrent wheeze. Evidence on the effectiveness of early anti-inflammatory therapy in the prevention of recurrent wheeze is conflicting, ${ }^{8-10}$ and the use of inhaled glucocorticoids varies greatly among countries. ${ }^{11-15}$ Thirty per cent of paediatricians in Switzerland reported that they always start inhaled glucocorticoids in patients admitted to hospital with respiratory syncytial virus related lower respiratory tract infection whereas $11 \%$ of paediatricians in Ireland selected such treatment in the case of a three month old infant with moderately severe disease. ${ }^{145}$ No large trials have studied the effect of inhaled glucocorticoids on recurrent wheeze after respiratory syncytial virus infection, ${ }^{16}$ preventing strong recommendations on the use of inhaled glucocorticoids. We carried out a large randomised double blind placebo controlled trial to investigate whether early initiated high dose extra fine hydrofluoroalkane (HFA) beclometasone diproprionate for three months after admission to hospital for respiratory syncytial virus infection prevents recurrent wheeze.

\section{METHODS}

The RSV Corticosteroid Study is a multicentre, randomised double blind placebo controlled trial 
comparing early initiated high dose extra fine HFA beclometasone with placebo in infants aged less than 13 months admitted to hospital for lower respiratory tract infection and with a positive immunofluorescence result for respiratory syncytial infection in epithelial cells from nasopharyngeal aspirates. We excluded infants who had previously been given steroids, had a history of cardiac or pulmonary disease, or had had a previous illness with wheeze. Recruitment took place during the winter seasons from November 2004 to February 2006 in the paediatric departments of 19 clinical centres in the Netherlands. Written informed consent was obtained from the infants' parents. Good clinical practice guidelines were followed.

\section{Randomisation}

Eligible infants were randomly assigned to receive either extra fine HFA beclometasone dipropionate or placebo. Randomisation was by means of a computer generated list of six numbers in each block and fixed blocks within each hospital. Local investigators at the paediatric departments enrolled infants and provided boxes containing the allocated treatment. Blinding was achieved by using active and placebo drugs of identical shape and taste. The doctors, nurses, parents, and investigators were unaware of the randomisation codes until data entry was complete.

\section{Study intervention}

Interventions were $200 \mu \mathrm{g}$ extra fine HFA beclometasone dipropionate (Qvar; 3M, TevaPharma, Haarlem, the Netherlands) twice daily or matching placebo given by pressurised metered dose inhalers and a spacer (Aerochamber; Trudell International Europe, Nottingham). The extra fine beclometasone formulation has smaller particles than conventional inhaled glucocortiocosteroids and is possibly more effective. ${ }^{17}$ Treatment was started within 24 hours of respiratory syncytial virus being detected and continued for three months. Treatment in infants with severe disease who needed mechanical ventilation was started within 24 hours of extubation. Asthma nurses taught the patients' parents correct inhaler techniques. Parental competence was evaluated three weeks after hospital discharge in 177 infants. Performance was scored on six items according to modified criteria of the Dutch Asthma Foundation ${ }^{18}$ (shaking of the inhaler, correct assembly of spacer and canister, activation of the canister, no more than three puffs at the same time, inhalation during at least 10 seconds, moving spacer valve). Median scores for performance in both groups were 6 (interquartile range 5-6).

Infants were followed up for one year after completion of treatment, during which time we determined the number of days with wheeze (the primary outcome measure). At the discretion of the paediatricians at the clinical centres, open label bronchodilators could be added to the study treatment if required. If steroid therapy was necessary, study treatment was discontinued.

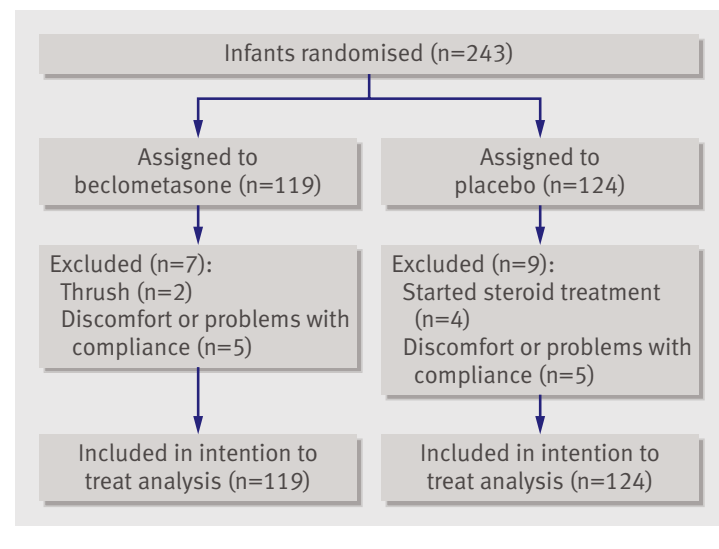

Fig 1 | Flow of patients through study

Primary and secondary outcome measures

Parents recorded airway symptoms and the use of airway drugs in a daily log. ${ }^{19}$ The logs were kept for 15 months from the start of intervention. They were returned to the investigators every three months. Parents were instructed how to complete the logs by a single investigator and telephone calls were scheduled every three months for motivational purposes.

The primary outcome was the number of days with wheeze. Secondary outcomes were the number of days with cough, the number of days using airway drugs, duration of hospital stay, health related quality of life, lung function, potential adverse effects of treatment on growth, and incidence of thrush. We assessed health related quality of life with the TNO-AZL preschool children quality of life questionnaire ${ }^{20}$ during the winter season one year after admission to hospital. The infants were tested for lung function and bronchial responsiveness at age 2 years by measuring interrupter resistance using a transducer (MicroRint; Micro Medical, Rochester, Kent). The interrupter technique measures changes in mouth pressure after a brief interruption of airflow at the mouth. It is based on the principle that the alveolar pressure and mouth pressure equilibrate within a few milliseconds of brief interruption of airflow. Airway resistance can be calculated from the ratio of mouth pressure to airflow at the mouth just before occlusion, ${ }^{21}$ and this was measured before and after administration of $400 \mu \mathrm{g}$ of inhaled salbutamol using a spacer. Growth was evaluated by measuring height at age 2 years.

To obtain data on respiratory symptoms, allergy, parental smoking, and allergy symptoms among first degree family members we used an extended Dutch version of the standardised questionnaire of the British Medical Research Council and the Dutch version of the European community respiratory health survey questionnaire. $^{22} 23$

\section{Statistical analysis}

The sample size was based on prevalence data for the primary outcome obtained from our previous followup study on respiratory syncytial virus bronchiolitis. ${ }^{19}$ In that cohort, $80 \%$ of infants wheezed at any time, with 
a mean number of days with wheeze during the 4 to 15 months after infection of 34.2 (95\% confidence interval 26.2 to 42.3 days). The predefined target of 250 patients provided at least $90 \%$ power to detect a clinically relevant difference of 14 days with wheeze between both arms.

We analysed the effects of beclometasone on the occurrence of any wheeze, cough, use of airway drugs, and thrush during follow-up. Percentages and associated 95\% confidence intervals of infants with any symptoms were calculated. We counted the number of days with symptoms or drug use, or both, to evaluate the effect of treatment on the severity of wheeze, cough, and drug use. As a typical Poisson distribution for probability arose we used Poisson regression analysis to study potential differences in number of days with wheeze and cough and in days of airway drug use. Duration of hospital stay (days), quality of life domain scores, measurements of interrupter resistance $(\mathrm{kPA} /$ $\mathrm{L} / \mathrm{s})$, and height $(\mathrm{cm})$ are expressed as medians and means. We used $\chi^{2}$ tests, Student's $t$ tests, and Mann Whitney $\mathrm{U}$ test to evaluate differences in percentages, mean values, and median values between the groups. To detect possible effect modification we carried out two prespecified subgroup analyses - the need for mechanical ventilation (yes $v$ no) and the presence of signs indicating airflow limitation during initial respiratory syncytial virus infection - that is, doctor diagnosed wheeze by auscultation (yes $v$ no). ${ }^{24}$

To decrease bias and increase statistical efficiency, we imputed missing data for quality of life domain scores, interrupter resistance measurements, duration of hospital stay, height, and presence of thrush. Imputation was done using the linear regression method (missing value analyses) available in SPSS for Windows version 13.0 software. ${ }^{2526}$ Such imputation is based on the correlation between each variable with missing values and all other variables as estimated from

Table 1|Baseline characteristics of infants with respiratory syncytial virus infection randomly assigned to receive extra fine hydrofluoroalkane beclometasone or placebo. Values are percentages unless stated otherwise

\begin{tabular}{|c|c|c|}
\hline Characteristics & $\begin{array}{l}\text { Beclometasone group } \\
\qquad(\mathrm{n}=119)\end{array}$ & $\begin{array}{l}\text { Placebo group } \\
\quad(n=124)\end{array}$ \\
\hline Male & 52 & 52 \\
\hline White & 85 & 84 \\
\hline $\begin{array}{l}\text { Median (interquartile range) duration of illness } \\
\text { before admission to hospital (days) }\end{array}$ & $3(1-4)$ & $2(1-4)$ \\
\hline $\begin{array}{l}\text { Median (interquartile range) age at admission to } \\
\text { hospital (months) }\end{array}$ & $2(1-4)$ & $2(1-5)$ \\
\hline $\begin{array}{l}\text { Admitted to intensive care unit, needing } \\
\text { mechanical ventilation }\end{array}$ & 9 & 9 \\
\hline $\begin{array}{l}\text { Median (interquartile range) gestational age } \\
\text { (weeks) }\end{array}$ & $39.5(37.5-40.6)$ & $39.5(37.5-40.6)$ \\
\hline Breast fed for at least one month & 66 & 58 \\
\hline $\begin{array}{l}\text { Signs of airflow limitation during initial } \\
\text { respiratory tract infection }\end{array}$ & 60 & 51 \\
\hline Maternal smoking before birth & 18 & 10 \\
\hline Median (interquartile range) atopy score* & $1(0-3)$ & $1(0-3)$ \\
\hline
\end{tabular}

*Semiquantitative parental score for atopy. One point added to score for presence of each atopic symptom (eczema, hay fever, bronchitis, asthma, and food allergy). ${ }^{27}$ the full dataset of participants with complete data. All analyses were done on an intention to treat basis, implying that no adjustments were made for the need for steroid treatment during the intervention period. In addition we carried out analyses on infants with complete log data (complete case analyses).

\section{RESULTS}

A total of 323 parents were asked if their child could participate in this intervention study; 78 were excluded for various reasons (previous use of steroids, cardiac history, not willing to participate). Overall, 243 infants were randomised: 119 to extra fine HFA beclometasone and 124 to placebo (fig 1). Table 1 shows the baseline characteristics of both groups. During the year of observation airway symptoms were recorded for 2305 months (79\% of total months). The median duration of follow-up for both groups was 15 months (interquartile range 12-15 months).

Airway symptoms and use of drugs during observation year

Table 2 shows the number of days with symptoms and the number of days using airway drugs during the year of observation. During the entire year of observation the number of days with wheeze in the total group and in the predefined subgroup of infants with signs of airway limitation during infection was similar but was lower in the subgroup of non-ventilated infants treated with beclometasone $(n=221)$. An absolute reduction in days with wheeze of $2.1 \%$ was observed (total days, $2120 / 33149(6.4 \%)$ in the placebo group $v 1315 / 30405$ $(4.3 \%)$ in the beclometasone group, $\mathrm{P}=0.046)$, a relative reduction of $32 \%$. Infants treated with beclometasone also had fewer days with cough. No other differences were observed. Results were similar with complete case analyses.

Figure 2 shows the distribution of days with wheeze during follow-up in the two treatment groups. To gain insight into the short term effects of intervention, Poisson analyses were carried out separately for the first six months of the observation year and the second six months. These retrospective Poisson analyses showed a more pronounced reduction in the number of days with wheeze during the first six months than during the second six months in the total group (total days, 1354/19 $048(7.1 \%)$ in the placebo group $v 949 /$ $17664(5.4 \%)$ in the beclometasone group, $\mathrm{P}=0.18)$ and in the subgroup of non-ventilated infants (total days, $1265 / 17215(7.3 \%)$ in the placebo group $v 683 / 16043$ $(4.3 \%)$ in the beclometasone group, $\mathrm{P}=0.02)$. No differences were observed in the subgroup of infants with signs of airflow limitation during infection (total days, 569/9752 (5.8\%) in the placebo group $v$ 599/ $10116(5.9 \%)$ in the beclometasone group, $\mathrm{P}=0.96)$.

The proportion of infants with wheeze, with cough, and using airway drugs did not differ between the placebo and beclometasone groups during follow-up (wheeze 62\% $v 61 \%$, cough $86 \%$ v 83\%, use of bronchodilators $42 \% \quad v \quad 40 \%$, use of steroids $26 \% v$ 

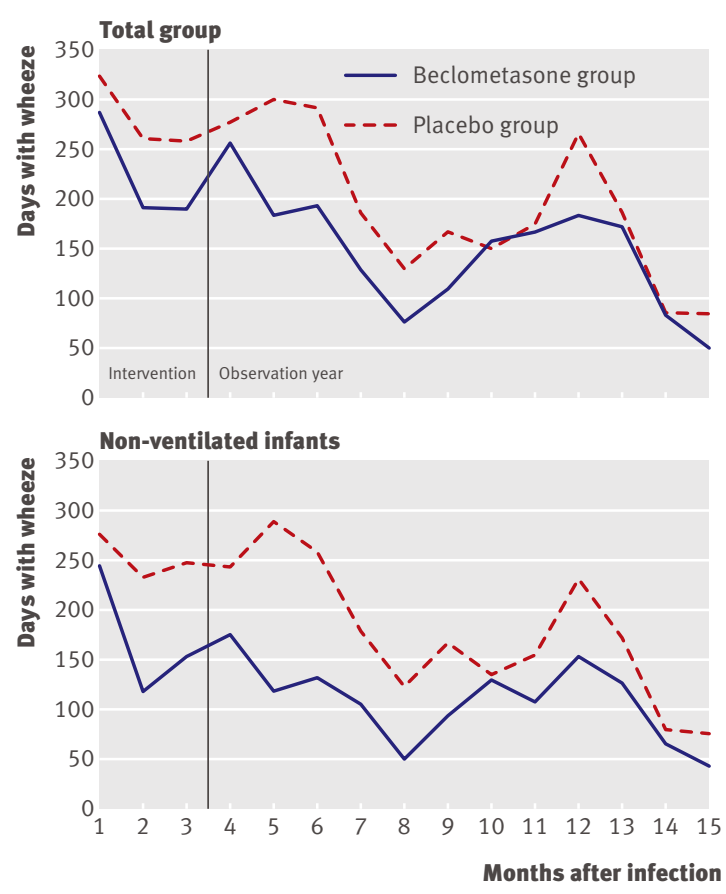

Fig 2 Days with wheeze during observation year in total group of infants (Poisson $P=0.31$ ) and in subgroup not needing mechanical ventilation (Poisson $\mathrm{P}=0.05$ )

$25 \%$ ). Comparable results were obtained in the two predefined subgroups.

\section{Secondary outcomes and adverse events}

The median duration of hospital stay was similar in both groups (4 days (interquartile range 3-8 days) in the placebo group $v 5$ (4-8) days in the beclometasone group, $\mathrm{P}=0.07)$. The TNO-AZL preschool children quality of life questionnaire, completed during the winter season one year after admission to hospital, was returned by 191 parents (79\%). Comparison of the domain scores for stomach problems, skin problems, lung problems, sleeping, appetite, liveliness, positive mood, problem behaviour, anxiety, social functioning, motor functioning, and communication showed that infants in the beclometasone group had lower scores for appetite than infants in the placebo group (median score 67 (intequartile range 50-100) v 83 (50-100), $\mathrm{P}=0.03$ ). At the end of the study, weight did not differ between the groups.

Measurement of airways resistance during the summer season in 2 year olds was successfully carried out in 91 of 163 children (56\%). No differences were found in percentage of successful measurements, baseline interrupter resistance, and interrupter resistance after inhalation of salbutamol between the two treatment groups (mean baseline interrupter resistance $1.15 \mathrm{kPA} / \mathrm{L} / \mathrm{s}$ (95\% confidence interval 1.10 to 1.19 $\mathrm{kPA} / \mathrm{L} / \mathrm{s}$ ) in the placebo group $v 1.10 \mathrm{kPA} / \mathrm{L} / \mathrm{s}(1.03$ to 1.17) in the beclometasone group, $\mathrm{P}=0.9$ ).

No severe adverse events were reported. Two infants in the beclometasone group had treatment stopped prematurely because of repeated thrush during the intervention period; however, the number of infants with thrush was similar in both groups (41/124 in the placebo group $v 47 / 119$ in the beclometasone group, odds ratio 1.3 (95\% confidence interval 0.8 to 2.2 ), $\mathrm{P}=0.3)$. Height at age 2 was similar in both groups (mean $86.8 \mathrm{~cm}$ (95\% confidence interval 86.2 to 87.5 $\mathrm{cm}$ ) in placebo group $v$ mean $86.9 \mathrm{~cm}$ (86.2 to 87.7), $\mathrm{P}=0.8$ ) in beclometasone group.

\section{DISCUSSION}

Early initiated high dose extra fine HFA beclometasone given to infants ( $<13$ months) for three months after respiratory syncytial virus related lower respiratory tract infection did not prevent recurrent wheeze. The number of days with wheeze in infants who did not require mechanical ventilation during infection showed a modest reduction from $6.4 \%$ to $4.3 \%$; a relative reduction of $32 \%$. No positive effect of our intervention on health related quality of life was observed. We found no evidence of side effects with the intervention.

\section{Comparison with other studies}

No treatment during lower respiratory tract infections caused by respiratory syncytial virus has been shown convincingly to have a beneficial effect on the course of acute disease or on long term airways morbidity. A beneficial effect of leukotriene receptor antagonists was suggested ${ }^{28}$ but could not be replicated in a large double blind study ${ }^{29}$ The current trial was based on the hypothesis that early initiated high dose inhaled glucocorticoids modify the immune response after respiratory syncytial virus infection resulting in the reduction of recurrent wheeze. Although studies suggest that about one quarter of infants admitted to hospital with bronchiolitis receive corticosteroids, ${ }^{3031}$ the efficacy of these agents has not been shown consistently. Several studies have shown that corticosteroids are not effective in the acute treatment of respiratory syncytial virus infections. ${ }^{32-35} \mathrm{~A}$ randomised controlled trial carried out in a birth cohort at risk of asthma found no effect of inhaled glucocorticoids on the progression of episodic wheeze into persistent wheeze.$^{36}$ In addition, no disease modifying effect of a two year therapy of inhaled corticosteroids was observed in a third, treatment-free year in preschool children at high risk of asthma. ${ }^{37}$ The temporary effects of inhaled steroids in that study and our study are similar. The role of inhaled glucocorticoids in the prevention of recurrent wheeze after respiratory syncytial virus infection is of particular interest because the pathogenesis of such infections is thought to be distinct from that of other wheezing disorders in infancy. ${ }^{38}$ Episodic high doses of inhaled glucocorticoids have been shown to provide a partially effective strategy in children with episodic wheeze caused by viruses. ${ }^{39}$ Previous studies investigating whether inhaled glucocorticoids can reduce the occurrence of recurrent wheeze after respiratory syncytial virus infection have yielded conflicting data and had major limitations, including small sample size, low dosage of 
treatment, mean age older than 12 months at inclusion, and lack of accurate tools to measure long term airways morbidity. ${ }^{10} 162740-42$

\section{Strengths and limitations of study}

The major strength of our study is that high dose treatment with beclometasone was initiated early, within 24 hours of the diagnosis of respiratory syncytial virus infection. Furthermore, the effect on recurrent wheeze was specifically evaluated in the group of infants admitted to hospital because of respiratory syncytial virus infection. To our knowledge this is the first randomised controlled trial that was sufficiently powered to evaluate the effect of early high dose inhaled glucocorticoids on recurrent wheeze after respiratory syncytial virus infection.

Some of our findings merit further discussion. Firstly, the data suggest that inhaled beclometasone did not prevent or diminish recurrent wheeze after respiratory syncytial virus infection in the total group of infants. No decrease in the number of days with wheeze and a small decrease in the number of days with cough were observed. Quality of life scores and interrupter resistance did not differ between the beclometasone and placebo groups. However, the study might be confounded because infants with severe disease who needed mechanical ventilation were analysed along with infants with more mild disease who did not need mechanical ventilation. No benefit of inhaled beclometasone was observed in mechanically ventilated infants. The small number of infants in this subgroup impedes a conclusion about the effect of inhaled beclometasone on recurrent wheeze in ventilated infants. However, we speculate that the delayed start of treatment prevented a treatment induced modification of the disease's course. Furthermore, it is possible that infants with severe disease did not respond to inhaled beclometasone as a result of mechanical injury during supportive care or because of enhanced virus mediated lung damage at the time of the initial process. In the major subgroup of infants $(n=221)$ who did not need mechanical ventilation the number of days with wheeze fell from $6.4 \%$ to $4.3 \%$, a relative reduction of $32 \%$. The effect of inhaled beclometasone was most pronounced during the first six months after treatment. The beneficial effect of beclometasone that was observed in the short term might be due to reduced airway reactivity during that period. No differences in quality of life scores and interrupter resistance were observed between the two groups, measured at a time when the severity of wheeze was similar in both groups. Because the TNO-AZL preschool children quality of life questionnaire measures health related quality of life over the past three months only, the outcome might have been different if measurements were taken earlier.

Secondly, we found treatment with beclometasone to be ineffective in infants presenting with signs of airflow limitation during respiratory syncytial virus infection, a subgroup reported to be at increased risk of developing recurrent wheeze. ${ }^{24}$ This finding seems counterintuitive. The disease modifying effect of beclometasone on recurrent wheeze after respiratory syncytial virus infection might be limited to specific phenotypes. The relevance of the presence of signs of airflow limitation during such infection to both the development of recurrent wheeze and the effect of treatment needs further research.

Thirdly, the results might have been influenced by inadequate administration of and adherence to the

Table 2 | Total number of days with airway symptoms and use of drugs compared with total log days during follow-up of infants with respiratory syncytial virus infection allocated to extra fine hydrofluoroalkane beclometasone or placebo

\begin{tabular}{|c|c|c|c|c|c|c|}
\hline \multirow[b]{2}{*}{ Variables } & \multicolumn{2}{|c|}{ Beclometasone group } & \multicolumn{2}{|c|}{ Placebo group } & \multirow[b]{2}{*}{$P$ value* } & \multirow[b]{2}{*}{ Rate ratio } \\
\hline & Total log days & $\begin{array}{l}\text { Total days with } \\
\text { symptoms }\end{array}$ & Total log days & $\begin{array}{l}\text { Total days with } \\
\text { symptoms }\end{array}$ & & \\
\hline \multicolumn{7}{|l|}{ Total group $(n=243)$ : } \\
\hline Wheeze & \multirow{4}{*}{33568} & 1761 & \multirow{4}{*}{36556} & 2301 & 0.31 & 0.83 \\
\hline Cough & & 7341 & & 9585 & 0.03 & 0.83 \\
\hline Steroid use & & 2578 & & 3105 & 0.69 & 0.90 \\
\hline Bronchodilator use & & 2066 & & 2749 & 0.39 & 0.82 \\
\hline \multicolumn{7}{|l|}{$\begin{array}{l}\text { No need for mechanical } \\
\text { ventilation }(n=221) \text { : }\end{array}$} \\
\hline Wheeze & \multirow{4}{*}{30405} & 1315 & \multirow{4}{*}{33149} & 2120 & 0.05 & 0.68 \\
\hline Cough & & 6681 & & 8724 & 0.05 & 0.83 \\
\hline Steroid use & & 2055 & & 2916 & 0.34 & 0.77 \\
\hline Bronchodilator use & & 1725 & & 2332 & 0.39 & 0.81 \\
\hline \multicolumn{7}{|c|}{$\begin{array}{l}\text { Signs of airflow limitation } \\
\text { during respiratory tract } \\
\text { infection }(n=133) \text { : }\end{array}$} \\
\hline Wheeze & \multirow{4}{*}{19290} & 1148 & \multirow{4}{*}{18465} & 916 & 0.41 & 1.20 \\
\hline Cough & & 4084 & & 4377 & 0.37 & 0.89 \\
\hline Steroid use & & 1739 & & 1028 & 0.16 & 1.62 \\
\hline Bronchodilator use & & 1252 & & 1152 & 0.90 & 1.04 \\
\hline
\end{tabular}




\section{WHAT IS ALREADY KNOWN ON THIS TOPIC}

Evidence on the effectiveness of early anti-inflammatory treatment to prevent recurrent wheeze is conflicting

Despite this, inhaled glucocorticoids are in common use

\section{WHAT THIS STUDY ADDS}

Early initiated high dose beclometasone in infants in the three months after hospital admission for respiratory syncytial virus infection has no major effect on recurrent wheeze

drugs. However, most parents carried out all essential steps correctly for administering the drugs. Moreover, a sensitivity analysis for infants whose parents carried out all steps correctly did not change the results. We determined parental adherence to the treatment regimen in a subset of infants by weighing returned canisters. Most parents gave the prescribed drug twice daily during at least nine full weeks of the prescribed three months.

Fourthly, this study was powered to detect a difference of 14 days between both treatment arms. The difference of 14 days with wheeze was arbitrarily defined and we might have missed a smaller but important effect. The power was based on mean differences whereas we finally used Poisson regression analysis to study differences in numbers of days with wheeze, which detects smaller differences as statistically significant.

Fifthly, no other research group externally validated the logs kept by the parents. We used the logs in two groups and observed that the occurrence of wheeze was virtually identical between the groups. This similarity supported the internal validity of the information from the logs. Finally, not all parents returned complete log data for the follow-up period, and thus the selective loss of data could have biased the results. However, complete case analysis gave similar results, the response rate in this trial was high, and missing data were equally distributed over both treatment groups.

\section{Conclusions and policy implications}

A Cochrane review on inhaled corticosteroids in the prevention of recurrent wheeze could not provide strong recommendations because of the small number of participants and the inability to pool all clinical outcomes. ${ }^{16}$ We found that early initiated high dose extra fine HFA beclometasone in infants aged less than 13 months during the first three months after admission to hospital for respiratory syncytial virus infection did not reduce the severity of recurrent wheeze. Only in our a priori specified subgroup of non-ventilated children was a modest and temporary reduction in days with wheeze found. We therefore conclude that general use of early initiated high dose extra fine HFA beclometasone should not be advised in infants admitted to hospital for respiratory syncytial virus infections.

We thank the asthma nurses and students for their help with this project. Extra fine HFA beclometasone dipropionate (Qvar) was provided by $3 \mathrm{M}$ Teva Pharma (Haarlem, the Netherlands) and the Aerochamber was kindly provided by Trudell International Europe (Nottingham, United Kingdom) In addition to the authors, the following paediatricians participated in the Respiratory Syncytial Virus Corticosteroid Study Group: M ten BergeKuipers, St Antonius Hospital, Nieuwegein; J de Bie, Hofpoort Hospital, Woerden; D Blom, Academic Medical Centre, Amsterdam; R Bruinsma, Gelre Hospital, Apeldoorn; F Brus, Rijnstate Hospital, Arnhem;

M Colombijn, Beatrix Hospital, Gorinchem; G van Enk, Gelderse Vallei Hospital, Ede; K van der Ent, University Medical Centre, Utrecht; R van Gent, Maxima Medical Centre, Veldhoven; M Hoetjer, Meander Medical Centre, Amersfoort; A van der Kaaden, Hospital Hilversum, Hilversum; E van Leer, Groene Hart Hospital, Gouda; R de Moor, Twee Steden Hospital, Tilburg; A Nieuwenhuis, Jeroen Bosch Hospital, 's-Hertogenbosch; M Pekelharing, Diakonessen Hospital, Utrecht; C Smeets, St Elisabeth Hospital, Tilburg; E de Vries, Jeroen Bosch Hospital, 's-Hertogenbosch; A van Wermeskerken, Flevoziekenhuis, Almere; D van der Zwet-Fandri, Mesos Medical Centre, Utrecht.

Contributors: All authors conceived and designed the study, interpreted the results, and wrote the manuscript. MJJE recruited patients. MJJE and MMR analysed the data. LJB obtained the funding and was responsible for overall supervision of the study.

Funding: This study was supported by a grant from the Dutch Asthma Foundation (No 3.2.03.22). No financial support was obtained from pharmaceutical companies. The study drugs and inhalers were provided unconditionally by the manufacturers.

Competing interests: None declared.

Ethical approval: This study was done in accordance with the principles of the Declaration of Helsinki and was approved by the ethics review committee of the University Medical Centre Utrecht and the ethics review committees of the participating centres.

1 Bont L, Steijn M, van Aalderen WM, Brus F, Th Draaisma JM, Diemen-Steenvoorde RA, et al. Seasonality of long term wheezing following respiratory syncytial virus lower respiratory tract infection. Thorax 2004;59:512-6.

2 Perez-Yarza EG, Moreno A, Lazaro P, Mejias A, Ramilo O. The association between respiratory syncytial virus infection and the development of childhood asthma: a systematic review of the literature. Pediatr Infect Dis / 2007;26:733-9.

3 Stein RT, Sherrill D, Morgan WJ, Holberg C), Halonen M, Taussig LM, et al. Respiratory syncytial virus in early life and risk of wheeze and allergy by age 13 years. Lancet 1999;354:541-5.

4 Kuehni CE, Davis A, Brooke AM, Silverman M. Are all wheezing disorders in very young (preschool) children increasing in prevalence? Lancet 2001;357:1821-5.

5 Bont L, Steijn M, van Aalderen WM, Kimpen JL. Impact of wheezing after respiratory syncytial virus infection on health-related quality of life. Pediatr Infect Dis / 2004;23:414-7.

6 Stevens CA, Turner D, Kuehni CE, Couriel JM, Silverman M. The economic impact of preschool asthma and wheeze. Eur Respir J 2003;21:1000-6.

7 Agertoft L, Pedersen S. Effect of long-term treatment with inhaled budesonide on adult height in children with asthma. N Engl J Med 20 0012;343:1064-9.

8 Reijonen T, Korppi M, Kuikka L, Remes K. Anti-inflammatory therapy reduces wheezing after bronchiolitis. Arch Pediatr Adolesc Med 1996;150:512-7.

9 Carlsen KH, Leegaard J, Larsen S, Orstavik I. Nebulised beclomethasone dipropionate in recurrent obstructive episodes afte acute bronchiolitis. Arch Dis Child 1988;63:1428-33.

10 Kajosaari M, Syvanen P, Forars M, Juntunen-Backman K. Inhaled corticosteroids during and after respiratory syncytial virusbronchiolitis may decrease subsequent asthma. Pediatr Allergy mmunol 2000;11:198-202.

11 Chauliac ES, Silverman M, Zwahlen M, Strippoli MP, Brooke AM, Kuehni AC. The therapy of pre-school wheeze: appropriate and fair? Pediatr Pulmonol 2006;41:829-38.

12 Kimpen JL, Schaad UB. Treatment of respiratory syncytial virus bronchiolitis: 1995 poll of members of the European Society for Paediatric Infectious Diseases. Pediatr Infect Dis / 1997;16:479-81.

13 Plint AC, Johnson DW, Wiebe N, Bulloch B, Pusic M, Joubert G, et al. Practice variation among pediatric emergency departments in the treatment of bronchiolitis. Acad Emerg Med 2004;11:353-60.

14 Cahill P, Finan E, Loftus BG. Management of bronchiolitis: current practices in Ireland. Ir Med J 2002 Jun;95(6):167-9.

15 Barben J, Hammer J. Current management of acute bronchiolitis in Switzerland. Swiss Med Wkly 2003;133:9-15.

16 Blom D, Ermers M, Bont L, van Aalderen WM, van Woensel JB. Inhaled corticosteroids during acute bronchiolitis in the prevention of postbronchiolitic wheezing. Cochrane Database Syst Rev 2007;(1) CD004881. 
17 Janssens HM, de Jongste JC, Hop WC, Tiddens HA. Extra-fine particle improve lung delivery of inhaled steroids in infants: a study in an upper airway model. Chest 2003;123:2083-8.

18 Kamps AW, van Ewijk B, Roorda RJ, Brand PL. Poor inhalation technique, even after inhalation instructions, in children with asthma. Pediatr Pulmonol 2000;29:39-42.

19 Bont L, Heijnen CJ, Kavelaars A, van Aalderen WMC, Brus F, Draaisma JT, et al. Monocyte IL-10 production during respiratory syncytial virus bronchiolitis is associated with recurrent wheezing in a one-year follow-up study. Am J Respir Crit Care Med 2000;161:1518-23.

20 Bunge EM, Essink-Bot ML, Kobussen MP, Suijlekom-Smit LW, Moll HA, Raat H. Reliability and validity of health status measurement by the TAPQOL. Arch Dis Child 2005;90:351-8.

21 Arets HG, Brackel HJ, van der Ent CK. Applicability of interrupter resistance measurements using the MicroRint in daily practice. Respir Med 2003;97:366-74.

22 Burney PG, Luczynska C, Chinn S, Jarvis D. The European Community Respiratory Health Survey. Eur Respir / 1994;7:954-60.

23 Rijcken B. Het Europees luchtwegonderzoek Nederland. Tijdschr Soc Gezondheidsz 1992;(70):259-60.

24 Bont L, van Aalderen WM, Versteegh J, Brus F, Draaisma JT, Pekelharing-Berghuis $\mathrm{M}$, et al. Airflow limitation during respiratory syncytial virus lower respiratory tract infection predicts recurrent wheezing. Pediatr Infect Dis / 2001;20:277-82.

25 Greenland S, Finkle WD. A critical look at methods for handling missing covariates in epidemiologic regression analyses. Am J Epidemiol 1995;142:1255-64.

26 Harrell FEJr, Lee KL, Mark DB. Multivariable prognostic models: issue in developing models, evaluating assumptions and adequacy, and measuring and reducing errors. Stat Med 1996;15:361-87.

27 Ermers MJ, Hoebee B, Hodemaekers HM, Kimman TG, Kimpen IL, Bont L. IL-13 genetic polymorphism identifies children with late wheezing after respiratory syncytial virus infection. J Allergy Clin Immunol 2007;119:1086-91.

28 Bisgaard $\mathrm{H}$. A randomized trial of montelukast in respiratory syncytial virus postbronchiolitis. Am J Respir Crit Care Med 2003;167:379-83.

29 Bisgaard H, Flores-Nunez A, Goh A, Azimi P, Halkas A, Malice MP, et al. Study of montelukast for the treatment of respiratory symptoms of post-RSV-bronchiolitis in children. Am J Respir Crit Care Med 2008;178:854-60.
30 Behrendt CE, Decker MD, Burch DJ, Watson PH. International variation in the management of infants hospitalized with respiratory syncytial virus. International RSV Study Group. Eur J Pediatr 1998;157:215-20.

31 Christakis DA, Cowan CA, Garrison MM, Molteni R, Marcuse E, Zerr DM. Variation in inpatient diagnostic testing and management of bronchiolitis. Pediatrics 2005;115:878-84.

32 Corneli HM, Zorc JJ, Majahan P, Shaw KN, Holubkov R, Reeves SD, et al. A multicenter, randomized, controlled trial of dexamethasone for bronchiolitis. N Engl J Med 2007;357:331-9.

33 De Boeck K, Van der Aa N, Van Lierde S, Corbeel L, Eeckels R. Respiratory syncytial virus bronchiolitis: a double-blind dexamethasone efficacy study. J Pediatr 1997;131:919-21.

34 Bulow SM, Nir M, Levin E, Friis B, Thomsen LL, Nielsen JE, et al. Prednisolone treatment of respiratory syncytial virus infection: $a$ randomized controlled trial of 147 infants. Pediatrics 1999;104:e77.

35 Roosevelt G, Sheehan K, Grupp-Phelan J, Tanz RR, Listernick R. Dexamethasone in bronchiolitis: a randomised controlled trial. Lancet 1996;348:292-5.

36 Bisgaard H, Hermansen MN, Loland L, Halkjaer LB, Buchvald F. Intermittent inhaled corticosteroids in infants with episodic wheezing. N Engl J Med 2006;354:1998-2005.

37 Guilbert TW, Morgan WJ, Zeiger RS, Mauger DT, Boehmer SJ, Szefler SJ, et al. Long-term inhaled corticosteroids in preschool children at high risk for asthma. N Engl J Med 2006;354:1985-97.

38 Bont L, Kimpen JL, Ermers MJ. Inhaled corticosteroids and children. $N$ Engl J Med 2006;355:624-5.

39 McKean M, Ducharme F. Inhaled steroids for episodic viral wheeze of childhood. Cochrane Database Syst Rev 2000;(2):CD001107.

40 Richter H, Seddon P. Early nebulized budesonide in the treatment of bronchiolitis and the prevention of postbronchiolitic wheezing. J Pediatr 1998;132:849-53.

41 Fox GF, Everard ML, Marsh MJ, Milner AD. Randomised controlled trial of budesonide for the prevention of post-bronchiolitis wheezing. Arch Dis Child 1999;80:343-7.

42 Lehtinen P, Ruohola A, Vanto T, Vuorinen T, Ruuskanen O, Jartti T. Prednisolone reduces recurrent wheezing after a first wheezing episode associated with rhinovirus infection or eczema. J Allergy Clin Immunol 2007;119:570-5.

Accepted: 19 November 2008 